\title{
Food Security and Human Development: Difference between Potential and Reality in ASEAN Countries
}

\author{
Jakaria $^{1}$, Justine Tanuwijaya ${ }^{2}$, Muhamad Yudhi Lutfi ${ }^{3}$ \\ \{justine@trisakti.ac.id $\left.{ }^{2}\right\}$ \\ Faculty of Economics and Business, Universitas Trisakti ${ }^{1,2,3}$
}

\begin{abstract}
Most of the countries in ASEAN are agriculture based country such as Indonesia, Thailand, Philippines, Vietnam, Laos and Cambodia. Facts show that the food security condition of ASEAN countries based on agriculture has a low food security rating, while countries such as Singapore have the highest food security ranking in the world. The purporse of this paper is to mapping Asian food security in terms of afffordability, availability, quality \& safety and natural resources and to proof the impact of food security on human development.The research design used is a quantitative research with comparative performance index and panel regression. The sample used in this study was 9 counteries in ASEAN with a time series period 2012-2020. The findings show that the condition of food security in ASEAN countries is a contribution from the aspect of affordability and quality and safety, while the aspect of availability and natural resources has a low contribution. The results of the regression panel show that the dimensions of food security that are proven to have a significant effect on human development are affordability, quality \& safety and natural resourches, while the dimensions of availability is not proven.
\end{abstract}

Keywords: Food Security; Affordability; Availability; Quality \& Safety; Natural Resources

\section{Introduction}

The Sustainable Development Goals (SDGs) place humans as the main goal of achieving goals. Of the 17 targets for achieving the SDGs, the first five goals are closely related to humans, namely (1) Without poverty, (2) Without hunger, (3) Having good and prosperous barriers, (4) Having quality education and (5) Gender Equality as shown in figure 1. This displays that development is a very important issue to be raised in research, both in the micro and macro scope. 


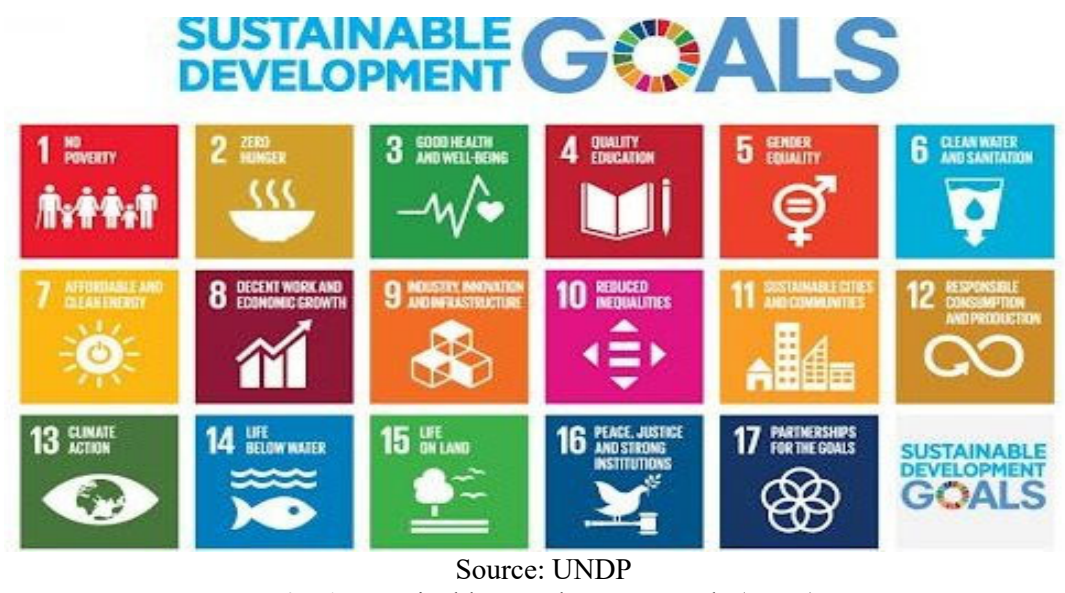

Fig. 1. Sustainable Development Goals (SDgs)

The success of human development based on measurements from UNDP includes the health dimension (average life expectancy), the education dimension (average length of schooling and average school expectation) and the economic dimension (average per capita expenditure). Most of the previous researchers raised the problem of human development by looking at the determinants that have an indirect effect on human development such as the level of poverty, labor force participation, the level of inequality. This study uses a direct influence approach from human development, namely using food security as a factor that is closely related to human development. With good food security will produce healthy humans so that it will improve the health dimension through increasing life expectancy. Good food security is believed to have apositive effect on the readiness of students in carrying out their education so that it will increase the averagelength of schooling.

Through good food security, it will also upgrade high employee productivity so that itwill linearly escalate workers' income which will automatically improve the welfare of the community as measured by average perapita expenditure. Food security is multidimensional in nature, which is not only related to the problem of food availability but also includes other aspects such as affordability, quality \& safety and natural resources. Indonesia as arich countr in food sources but in reality only places it in a relatively low position, namely ranked 65th in the world and this ranking is much lower than Singapore which is the first ranked in the world in 2018. Malaysia with a food security index value of $68.1 \%$ which is ranked 40 , Thailand with a food security indexvalue of $58.9 \%$ with a rank of 54 and Vietnam which is ranked 62 with a food security index value of 62 . Indonesia is only higher than the Philippines with a food security index of $51.5 \%$ and is ranked 70 , Myanmar with an index of $45.7 \%$ and is ranked 82 , or Cambodia with a food security index value of $42.3 \%$ and is ranked 85 and Laos with a value of $38.3 \%$ and is ranked 90 [1]. For more details can be observedin Figure 2. 


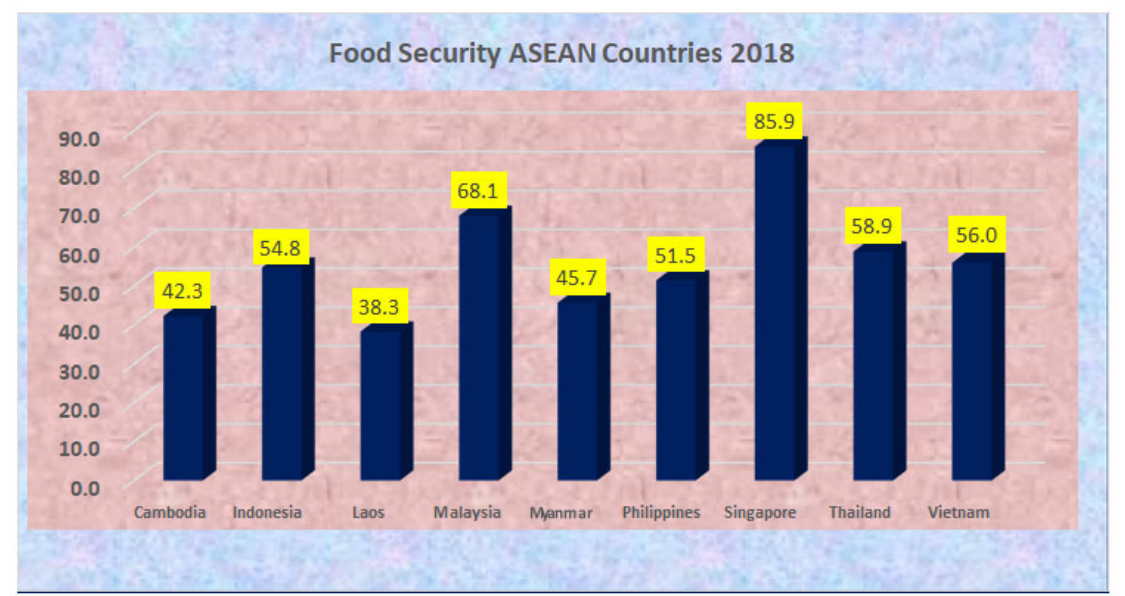

Source : GFSI, 2018

Fig. 2. ASEAN Food Security Index based on GFSI 2018

Empirical studies linking food security with human development are still relatively limited. Sow, Berete, \& Uche in their study found a positive connection between food security and human development [2].Verwimp in his research reinforces that conflicts that occur will affect food security and have an impact on human development [3]. Burchi \& Muro reinforce the strong negative relationship between food insecurity in African countries and human development [4]. Gani \& Prasad found that the dimensions of food security (food availability and supply of calories and protein had a positive effect on human development [5]. The food accessibility dimension found that the higher the price of food and the morevulnerable to food, the lower human development. Based on the explanation above, this research was conducted by trying to relate food security with human development for the Southeast Asia region.

\section{Literature Review}

\subsection{Human Development}

The theory of human development was initiated by Amarya Sen in his book Development of Freedom which discusses human capabilities [6]. The human development approach explains the developmentprocess through improving the quality of human life and not just improving the economy of a country. Human development approach assumes that improving human life will be more meaningful if it has an effect on welfare and prosperity than only increasing economic capacity or economic growth. The conceptual framework of human development consists of 2 dimensions namely [6]:

1. Directly improve human abilities which include have :

a. A long and healthy life expectancy

b. Knowledge

c. A decent standard of living

2. Creating conditions for human development that include

a. Participate in political and community life 
b. Sustainable environmental development

c. Protect the safety and rights of every human being

d. Gender similarity

Measurement of human development was first introduced by the United Nations Development Program (UNDP) in 1990. Human development is related to the choices of society or human choices which are verynumerous and change over time. Periodically UNDP makes refinement in the calculation of the HDI and the measurement of the Human Development Index which was most recently issued by UNDP in 2014 using 3 dimensions, namely:

a. Length of life (longevity) as measured by Life Expectancy

b. Knowledge (knowledge) is measured by using 2 indicators, namely

1. Average length of schooling

2. Expectations of long schooling

c. Decent standard of living as measured by using GNI perk

The HDI value is in the interval range from 0 to 100 . The closer to 100 indicates the better human development and vice versa close to 0 indicates the worse human development.

\subsection{Food Security}

Food security has a very broad definition so that the definition of food security has developed according to needs. Although the notion of food security is relatively broad, one thing is certain that food security is veryimportant for all people in the world [7]. Ballenger and Mabbs- Zeno classify food security into three groups, namely (1) Global Food Security provided that the amount of food available is sufficient to meet the needs of the world community (global), (2) National FoodSecurity which requires food available for consumption in the country to be at least the same as food needs throughout the year, (3) Individual Food Security which means that the income of each individual (person)is sufficient to meet all their needs [8]. Barraclough and Utting stated that the food system has the following 5 characteristics: (1) The ability to produce adequate internal food supplies, (2) Has autonomy in determining its own destiny, (3) Reliable so that seasonal and cyclical variations to food can be minimized, (4) Have long-term sustainability and (5) There is a balance which means at least reliable access to food forall social classes, groups and strata [9].

The very broad concept of food security causes the various definition of food security. The following are some definitions of food security that are widely used as the basis for measuring the food security of an economy. The International Conference in Nutrition defines food security as the access of every household or individual to obtain food at any time for the purposes of healthy living [10]. The World Food Summit defines it as a condition in which all people have physical and economic access to sufficient, safe and nutritious food to meet their dietary needs and food preferences for an active and healthy life [11]. Law No: 12 of 2012 concerning Food defines food security as a condition for fulfilling food for the state to individuals, which is reflected in the availability of sufficient food, both in quantity and quality, safe, diverse, nutritious, equitable and affordable and does not conflict with religion. beliefs and culture ofthe community to be able to live a healthy, active and productive life in a sustainable manner. From these definitions of food security above, it can be concluded that aspects of food security include availability, access (affordability), quality, safety, stability and utilization. 


\subsection{Food Security Measurement}

The various definitions of food security cause the measurement of food security also have indicators. As previously stated, the definition of food security varies and involves very broad aspects, so the indicators, methods and data used by researchers to measure food security are also very varied. Therefore the measurement for food security is also very diverse. This study uses the measurement of food security according to The Economic Intelligence Unit (EIU) where the stages of food are divided into 4 dimensionsas shown in the figure 3 .

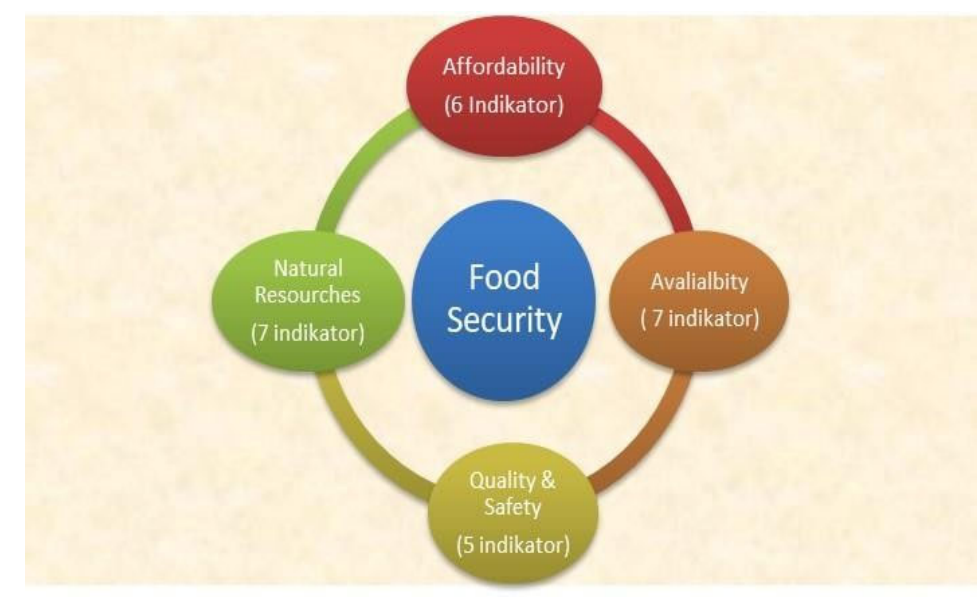

Source: The Economics Intelligence Unit, 2021

Fig. 3. Dimensions of the Global Food Security Index (GFSI)

\subsection{Previous Studies}

Empirical Study of the Relationship Between Food Security and Human Development Index (HDI). Empirical studies linking food security with human development are still relatively limited. Sow et al., in their research which aims to examine the linkage between food security and security indices withhuman development in Africa resulted in the conclusion that there was a significant positive relationship between safety and security index with human development [2]. Verwimp in his research resulted in the conclusion that conflicts that occur have an impact on people's sources of income which in turn affect human development in the long term [3]. UNDP (2012) in a study that aims to analyze how strong food security can accelerate Human Development. The findings claim that a person is in a condition of eating and nutritionally adequate, obtaining food safely, the amount of food that is varied and of good quality will increase his human resources (human development). Gani and Prasad support the existence of evidence of a significant relationship between food security and human development [5].

\subsection{Conceptual Framework}

The results of a literature study related to food security according to the IEU resulted in a measurement of food security which was formed from 4 dimensions, namely affordability, 
availability, quality \& safety and natural resources. Several empirical studies, as described above, have found that food security is proven to have an effect on human development. Crystallization from the literature study and the results of empirical studies produce a conceptual framework as displayed in Figure 4.

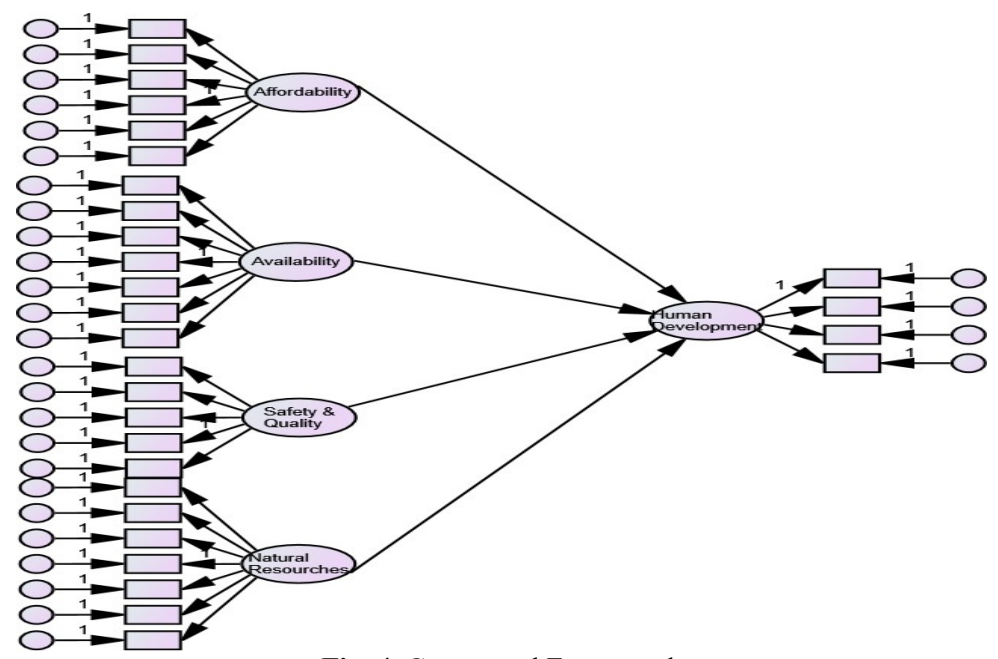

Fig. 4. Conceptual Framework

\subsection{Research Hypothesis}

Food Security version of the Global Food Security Index includes a new dimension in the measurement of food security, namely the dimension of natural resources. The results of empirical studies conducted by Sow et al.; Verwimp; UNDP (2012); and Gani and Prasad found that there was a positive influence of food security on human development. Based on this explanation, the hypothesis proposed in this study are as follows [2], [3], [5]:

H1a: Affordability dimension of food security has a positive effect on human development

H1b: Availability dimension of food security has a positive effect on human development

H1c: Quality \& safety dimension of food security has a positive effect on human development

H1d: Natural resources dimension of food security has a positive effect on human development

\section{Research Methodology}

\subsection{Research Design}

This study is correlational research which aims to investigate the influence of the independent variable, namely the food security variable which consists of 4 dimensions, namely affordability, availability and quality and safety as well as natural resources on the dependent variable, namely human development which is proxied through the Human Development Index. (HDI) 


\subsection{Variable and Measurement}

This study uses two variables, namely food security with 4 dimensions and the HDI which consists of 3 dimensions where the measurement of each variable is more clearly exhibited in table 1.

Table 1. Operational Research Variables

\begin{tabular}{|c|c|c|c|}
\hline Variable & Dimension & Indicator & Scale \\
\hline \multirow{24}{*}{ Food Security } & Affordability & 1. Change in average foot costs & Ratio \\
\hline & & $\begin{array}{l}\text { 2. Proportion of population under global } \\
\text { poverty line }\end{array}$ & Ratio \\
\hline & & 3. Inequality adjusted income index & Ratio \\
\hline & & 4. Agricultural import tariffs & Ratio \\
\hline & & 5. Food Safety net programs & Ratio \\
\hline & & $\begin{array}{l}\text { 6. Market access and agricultural } \\
\text { financial services }\end{array}$ & Ratio \\
\hline & Availability & 1. Sufficiency of supply & Ratio \\
\hline & & 2. Agricultural research and development & Ratio \\
\hline & & 3. Agricultural infrastructure & Ratio \\
\hline & & 4. Volatility of agricultural production & Ratio \\
\hline & & 5. Political and social barriers to access & Ratio \\
\hline & & 6. Food Loss & Ratio \\
\hline & & $\begin{array}{l}\text { 7. Food security and access policy } \\
\text { commitments }\end{array}$ & Ratio \\
\hline & Quality and Safety & 1. Dietary diversity & Ratio \\
\hline & & 2. Nutritional Standards & Ratio \\
\hline & & 3. Micronutrient availability & Ratio \\
\hline & & 4. Protein Quality & Ratio Ratio \\
\hline & & 5. Food safety & \\
\hline & Natural Resources & 1. Exposure & Ratio \\
\hline & and Resilience & 2. Water & Ratio \\
\hline & & 3. Land & Ratio \\
\hline & & 4. Oceans, rivers and lakes & Ratio Ratio \\
\hline & & 5. Sensitivity & Ratio Ratio \\
\hline & & $\begin{array}{l}\text { 6. Political commitment to adaption } \\
\text { 7. Demographic stress }\end{array}$ & \\
\hline \multirow{4}{*}{$\begin{array}{c}\text { Human } \\
\text { Development } \\
\text { Index (HDI) }\end{array}$} & Long life & Life expectancy & Ratio \\
\hline & dimension & & \\
\hline & Knowledge & 1. Average length of schooling & Ratio \\
\hline & $\begin{array}{l}\text { dimension decent } \\
\text { standard of living }\end{array}$ & $\begin{array}{l}\text { 2. Old school hopt Gross National Product } \\
\text { Per capita }\end{array}$ & Ratio \\
\hline
\end{tabular}

\subsection{Data and Sample}

All data used are secondary data with a structure in the form of panel data (pooled data). The cross section data used are ASEAN countries with complete data, namely Cambodia, Indonesia, Laos, Malaysia, Myanmar, Philippines, Singapore, Thailand and Vietnam. Time series data used for the period 2012-2020. The data sources used were obtained by conducting library research from various agencies, namely the Central Statistics Agency (BPS), United National Development Project (UNDP) and publications from theGlobal Food Security Index. For time series data used 2012-2020. 


\subsection{Analysis Tool}

\section{a) Food Security Index}

The calculation of the food security index is carried out in the following stages:

1. Identify the variables used to measure food security and determine the best value, whether it ismaximum or minimum.

2. Using the distance to scale method to change the value of each variable to be in the form of anindex where for the variable that has the best maximum value using the formulation:

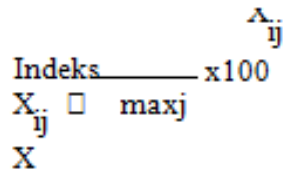

For variables whose indicators have a negative relationship to food security, the country with the lowestscore will get an index value of 100 while for other countries with a higher value it will have an index value below 100. The formulation for changing the index value for each variable that has a negative relationship with food security for each country is expressed by the formula:

$$
\begin{aligned}
& \begin{array}{l}
\text { In } \\
\text { ks }
\end{array} \quad \frac{\mathrm{Xminj}^{\mathrm{x} 100}}{\mathrm{X}_{i j}} \\
& \mathrm{X} \\
& \text { ij }
\end{aligned}
$$

Description:

Index $\mathrm{X}_{\mathrm{ij}}=$ index value of certain variable for country $\mathrm{i}$ year $\mathrm{j}$

$\mathrm{X}_{\max }=$ the maximum value for a certain variable in a certain country in year $\mathrm{j}$

$\mathrm{X}_{\min }=$ the minimum value for a certain variable in a certain country in year $\mathrm{j}$

3. Calculating the food security index for 4 dimensions, namely affordability, availability, safety \&quality and natural resources, using the following data:

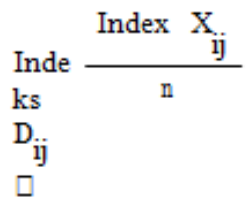

Description:

Dij $=$ The food security index of the th dimensionIndex

$\mathrm{Xij}=$ Food security index indicator $\mathrm{i}$ - year $\mathrm{j}$

$\mathrm{N}=$ Number of food security indicators of certain dimensions 


\section{b) Econometric Model}

The model that will be used is the pooling regression equation model with the consideration that the characteristics of ASEAN countries are relatively homogeneous except for Singapore. The regression equation model used is stated in the equation:

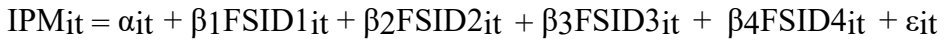

Description :

IPMit = HDI for country i period $\mathrm{t}$

FSID1 it $=$ HDI avaibility dimension for country $\mathrm{i}$ period $\mathrm{t}$

FSID2it = HDI affordability dimension for country period $\mathrm{t}$

FSID3it = HDI quality and safety dimension for country i period $\mathrm{t}$

FSID4 it $=$ HDI natural resources dimension for country i period $\mathrm{t}$

Tests carried out to answer research problems are implemented in stages:

1. Classical assumption test

This test aims to make the estimated coefficients produced meet the BLUES (Best Linear Unbiased Estimator) criteria. The conditions for the resulting coefficient to be BLUES must meet 4 assumptions, namely the fulfillment of assumptions

a. Normality is carried out using the Jarque Berra test where decision making is implemented with criteria:

If the $p$-value of Jarque Berra $>0.05$ then the normality of the model is met

If the $\mathrm{p}$-value of Jarque Berra $<0.05$ then the normality of the model is not met

b. Multicollinearity is carried out by using the Variance Inflation Factor (VIF) test where decisionmaking is carried out with criteria

If $\mathrm{VIF}<10$ then the assumption of multicollinearity is met

If $\mathrm{VIF}>10$ then the assumption of multicollinearity is not met

c. Autocorrelation testing using the LM test where decision making is carried out with criteriaIf the $\mathrm{p}$-value of the chi-square cross section $>0.05$, there is no autocorrelation If the $p$-value of the chi-square cross section $<0.05$, there is an autocorrelation

d. Heteroscedasticity testing using the Gletjer Test with decision making criteria If the $\mathrm{p}$-value of the independent variable $\mathrm{t}$ statistic $>0.05$ then there is no heteroscedasticity If the $p$-value of the independent variable $t$ statistic $<0.05$, then there is heteroscedasticity

2. Theoritical Hypothesis This stage consist of

a. Coefficient of Determination (R2)

Conducted to find out how much variation of the dependent variable can be explained by the variation of the independent variable $\mathrm{R} 2$ value between 0 to 1 where the closer to 0 the model is more unfit, while the closer to 1 the model is more fit.

b. Global Test (F Test)

Used to test whether there is at least one independent variable that affects the dependent variable. The proposed hypothesis

Ho $: 1=2=3=\ldots \ldots \ldots \ldots \ldots . . . .=n=0$ which means that all independent variables do not affect the dependent

variable

$\mathrm{H} 1$ : At least one $\mathrm{K} 0, \mathrm{k}=1,2, \ldots \ldots \ldots \mathrm{K}$ 
Which means that there is at least one independent variable that has a significant effect on thedependent variable

Decision making is done with criteria

If the p-value of Fstatistics $<0.05$ then Ho is rejected If the p-value of Fstatistics $>0.05$ then Ho is accepted

c. Partial Test ( $t$ test)

This test aims to test the effect of each independent variable on the dependent variable with thefollowing stages:

Ho : $\mathrm{i}=0$

which means the $\mathrm{i}$-th independent variable does not affect the dependent variable $\mathrm{H} 1$ : $\mathrm{i}$ 0

which means the i-th independent variable affects the dependent variable Decisionmaking

If tcount $>$ ttable then Ho is rejected

If the $\mathrm{p}$-value of tstatistic $<0.05$ then Ho is rejected

If the p-value of tstatistics $>0.05$ then Ho is accepted

\section{Results and Discussion}

\subsection{Descriptive Statistics}

\section{a) Food Security of ASEAN Countries}

Descriptive statistics for food security in ASEAN countries for the period 2012-2020 put Singapore as thecountry with the highest food security index at an average of $77.2 \%$, followed by Malaysia with an average food security index value of $67.81 \%$. Thailand is the third rank country for food security during the period 2012-220 with an average score of $64.08 \%$, followed by Myanmar which is in fourth position with an average score of $61.18 \%$ and Indonesia in fifth place with an average value of the food security index of $61.12 \%$. Loos is a country with the lowest food security index, which has an average value of 45.75 during the 2012-2020 period. These findings indicate that Singapore, Malaysia and Thailand are ASEAN countries that have a good food security score compared to other ASEAN countries. For more details refer Figure 5.

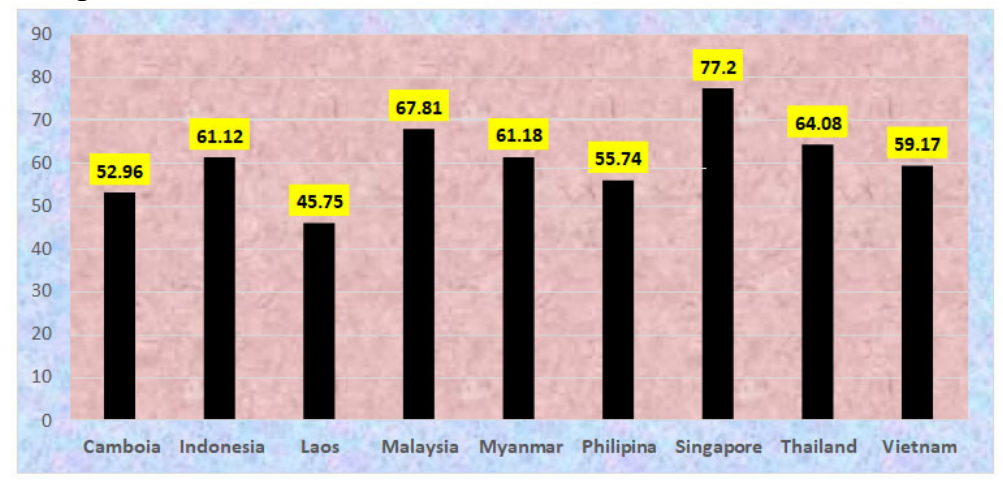

Source : GFSI data processed

Fig. 5. ASEAN Country Food Security Index 2012-2020 
Affordability is one of the dimensions used to determine the food security index. The results of processingthe food security index for the affordability dimension show that there are 4 countries that have an index with a value of more than $75 \%$, namely Malaysia in first place with a value of $89.96 \%$, followed by Thailandwith a value of $85.87 \%$, then by Singapore with a score of $89.96 \% .85 .65 \%$ and Indonesia with a value of $77.25 \%$. There are 3 countries with an index between $60 \%$ to $75 \%$, namely Myanmar with a score of $69.38 \%$, followed by the Philippines with a score of $65.41 \%$ and Vietnam with a score of $61.13 \%$ each. Two other countries, namely Cambodi, have an index. by $59.7 \%$ and the lowest is Laos with an index of $43.87 \%$. For more detailed information can be seen in Figure 6.

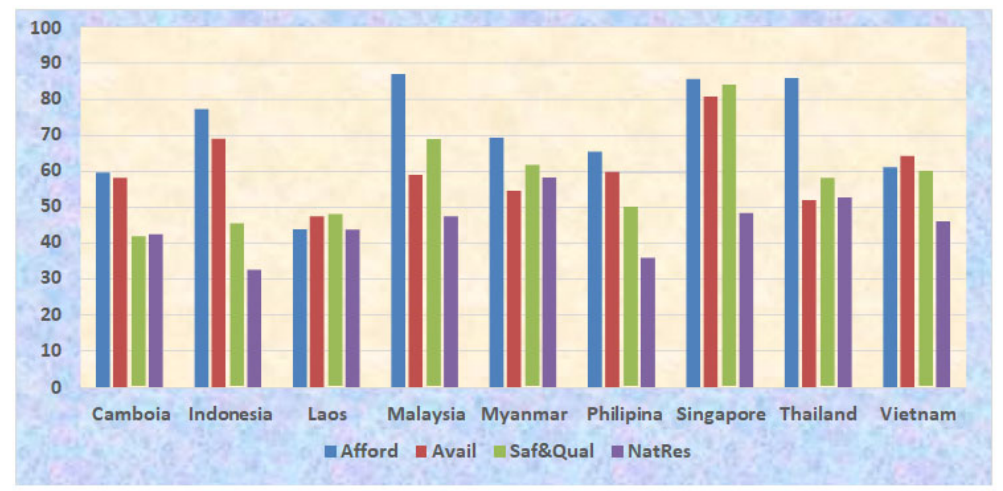

Source : GFSI data processed

Fig. 6. ASEAN Country Dimension Food Security Index

(Affordability, Availability, Quality \& Safety and Natural Resources) 2012-2020

The second dimension that forms food security is availability. The results of processing the ASEA countryavailability index for 2012-2020 Singapore is the only ASEAN country that has an availability index valuehigher than $75 \%$, which is $80.55 \%$. There are two countries that have availability index values between $60 \%$ and $75 \%$, namely Indonesia with an index of $69 \%$ and Vietnam with an index of $64.21 \%$. A total of 5 countries have an availability index between $50 \%$ and $60 \%$, namely the Philippines with an index of $59.77 \%$, followed by Malaysia with an index of $58.93 \%$, then Cambodia with an index of $58.15 \%$, Myanmar with an index of $54.55 . \%$ and Thailand with an index of $51.91 \%$. One country with an availability index below $50 \%$ is Laos with an index of $47.44 \%$.

In general, the food security index for the safety \& quality aspects of ASEAN countries is still low. Of the 9 countries that were used as research samples, there were 4 countries that had an index of less than $50 \%$, namely Cambodia with an index of $41.74 \%$, followed by Indonesia with an index of $45.37 \%$, then Laos with an index of $47.95 \%$ and the Philippines. with an index of $49.97 \%$. There are 2 countries that have an index between 50 and $60 \%$, namely Thailand with an index of $57.95 \%$ and Vietnam with an index of $59.98 \%$. Two countries have an index between 60 and 75\%, namely Myanmar with an index of $61.67 \%$ and Malaysia with an index of $68.85 \%$. Singapore is the only country in ASEAN that has a food security index of more than $75 \%$, which is $83.93 \%$.

Overall, the natural resources dimension is the weakest aspect of ASEAN countries in achieving food security. This can be appeared from the average achievement of the food security index for the natural resources aspect where none of the ASEAN countries achieves 
the index score for this dimension above $60 \%$. There are only 2 countries that achieve index scores between $50 \%$ and $60 \%$, namely Myanmar and Thailand with index scores of 58.13\% and $52.64 \%$, respectively. The remaining 7 other countries have an index below $50 \%$ and Indonesia ranks as the country with the lowest index achievement, which is $32.61 \%$.

\section{b) Human Development of ASEAN Countries}

The results of descriptive statistical processing for human development variables which are proxied using the Human Development Index (HDI) can be seen in table 6. Information from the table shows that Singapore is an ASEAN country with the highest human development achievement even when compared to other countries in the world, namely by achieving an average HDI value during the 2021-2020 period of 93.1\%. Malaysia ranks second in terms of achieving HDI with an average score of $79.85 \%$, followed by Thailand in third place with an average HDI score of $75.32 \%$. The Philippines is in fourth place with an average HDI index of $70.4 \%$ during the period 2012-2010, followed by Indonesia which is in fifth place with an average HDI value of $70.17 \%$. Vietnam is ranked sixth with an average HDI value of $69.21 \%$ whilethe remaining three countries have an average HDI score of less than $60 \%$, namely Laos with an average score of $59.97 \%$, followed by Cambodia with a high score of $59.97 \%$. The average HDI is $57.58 \%$ and thelowest is Myanmar with the average HDI achievement during the $2012-2020$ period of 56.34 .

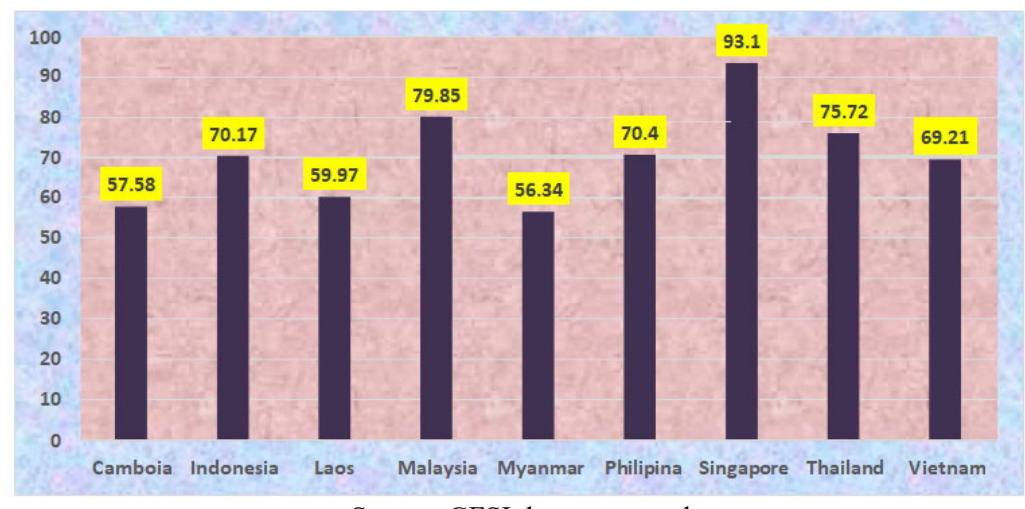

Source: GFSI data processed

Fig. 7. ASEAN Country Human Development Index 2012-2020

\subsection{Analysis of Research Results}

The regression model used in this study is multiple regression with pooled method, which combines time series and cross section data with the assumption that there is no difference in behavior between cross sections so that the regression model used is multiple regression. Before testing the theoretical hypothesis, the classical assumption test is first carried out where the test results are stated as follows:

\section{a) Classic Assumption Test}

The results of processing for classical assumption testing after heteroscedasticity 
improvements show thatfor normality testing using the Jarque Berra test, a p-value of 0.155> 0.05 is obtained, which means Ho is accepted so that it can be concluded that the error distribution is normal (normality assumption is met). Multicollinearity testing with using the VIF criteria produces a value of less than 10 for all independent variables used so that Ho is accepted, which means that there is no multicollinearity. The results of the autocorrelation test using the LM test produce a p-value of the LM test of $0.000<0.05$, which means Ho isrejected so that it can be concluded that the resulting model has autocorrelation. For heteroscedasticity testing using the glacier test, it was concluded that all variables did not occur heteroscedasticity at 5\% alpha except for the Quality \& Safett variable which passed the heteroscedasticity problem at an error rate of $1 \%$. The problem of autocorrelation is an important problem specifically for time series data, while this study uses panel data so that the existence of autocorrelation in this model is not a problem that must be overcome. For more clear information can be seen in table 2 .

\begin{tabular}{|c|c|c|c|c|}
\hline \multicolumn{5}{|c|}{ Dependent Variable : Absolute Residual } \\
\hline Variable & $p$-value $t$ & Conclusion & VIF & Conclusion \\
\hline Affordability & 0.848 & No heteroscedasticity & 2.667 & No multicollinearity \\
\hline Availability & 0.681 & No heteroscedasticity & 7.840 & No multicollinearity \\
\hline Safety \& Quality & 0.019 & No heteroscedasticity & 2.376 & No multicollinearity \\
\hline Natural Resources & 0.062 & No heteroscedasticity & 4.854 & No multicollinearity \\
\hline Prob Jarque Berra & 0,155 & Normal Distribution & & \\
\hline Prob LM Test & 0,000 & Autocorrelation & & \\
\hline
\end{tabular}

\section{b) Hypothesis Testing}

The processing results for testing the research hypothesis are shown in table 3 . Testing the fit model using adjusted R2 produces a value of 0.920 , which means that the variation of the independent variable, namelythe dimensions of food security (afforadility, availability, service \& quality and natural resources) is able to explain the variation of the dependent variable. namely HDI of $92 \%$ while the remaining $8 \%$ is a variation of other independent variables that affect HDI but are not included in the model. These results indicate thatthe resulting model has a good fit model. The global test ( $F$ test) produces a p-value of $F$ of $0.000<0.05$, which means Ho is rejected and $\mathrm{Ha}$ is accepted so that it can be concluded that there is at least one independent variable that is proven to have a significant effect on human development.

Hypothesis 1 was carried out with the purpose of testing the positive effect of affordability on human development. The processed results obtained an estimated coefficient of 0.230 which means that increasing affordability will increase human development and conversely decreasing affordability will reduce human development. With a t-statistical value of 5.030, a p-value of $0.000<0.05$ was obtained, then Ho was rejected and $\mathrm{Ha}$ was accepted, so it can be concluded that the positive effect of affordability on human development is proven.

Tablel 3. Human Development Model Regression

\begin{tabular}{ccccc}
\hline Variable & Coefficient & tstatistik & p-value & Conclusion \\
\hline Affordability & 0.230 & 5.030 & 0.000 & Supported \\
Availability & -0.062 & -0.733 & 0.232 & Not supported \\
Safety \& Quality & 0.7340 & 10.086 & 0.000 & Supported \\
\hline
\end{tabular}




\begin{tabular}{ccccc}
\hline Variable & Coefficient & tstatistik & p-value & Conclusion \\
\hline Natural Resourches & 47.125 & 7.803 & 0.000 & Supported \\
Adjusted R2 & 0,920 & & & \\
F statistic & 233,82 & & & \\
p-value & 0,000 & & & \\
\hline
\end{tabular}

Hypothesis 2 verifies the positive effect of availability on human development. From the processed results, the estimated coefficient is -0.062 , which means that increasing availability will decrease human development and conversely decreasing availability will increase human development. These findings indicate that the research hypothesis which states that availability has an effect on human development is not supported.

Hypothesis 3 was carried out with the aim of testing the positive effect of safety \& quality on human development. From the processed results obtained an estimated coefficient of 0.734 , which means that increasing safety \& quality will increase human development and conversely decreasing safety \& quality will reduce human development. With a t-statistical value of 10,086 , a p-value of $0.000<0.05$ was obtained so that Ho was rejected and Ha was accepted, so that it can be concluded that the positive influence of quality $\&$ safety on human development is significant.

Hypothesis 4 aims to examine the positive effect of natural resources on human development. It is obtained an estimated coefficient of 47.125 , which means that increasing natural resources will increase human development and conversely decreasing natural resources will decrease human development. With a t- statistic value of 7.803, a p-value of 0.000 $<0.05$ was obtained, so that Ho was rejected and Ha was accepted. Thus, it can be concluded that the positive influence of natural resources on human development is significant.

\subsection{Discussion}

The affordability dimension has a positive effect on human development, indicating that the affordability of the community to access to food is easily obtained, such as stable food prices, a small number of poor people, low food inequality, government policies to secure national food and market access and financial services for Cheap food commodities are proven to be effective in enhancing human development. This iswhat located Malaysia, Singapore and Thailand with a high index of food security, which is above $85 \%$ because the achievement of indicators from the affordability dimension of the country concerned has a high index. The opposite condition occurs with countries in ASEAN such as Laos, Cambodia which have high afforadility will produce a high HDI and vice versa. Scatter plot diagram of empirical data between affordability and human development dimensions of food security proves that there is a positive relationship between the two variables as shown in Figure 8. 


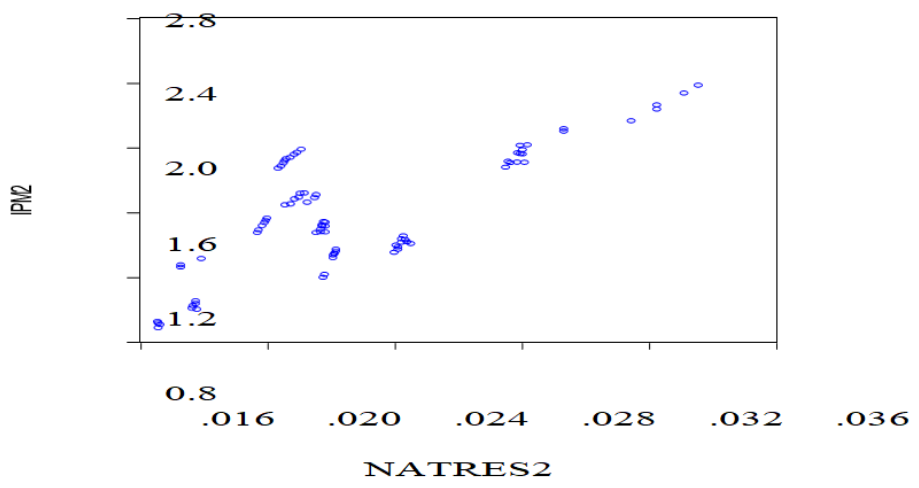

Fig. 8. Scatter Plot Affordability with Human Development

The dimensions of quality and safety has a significant positive effect indicating that food diversity, fulfillment of national nutritional standards, adequacy of the need for vitamins contained in food consumption, protein quality and availability of clean water that supports food consumption and the availability of places for safe food storage are factors of food security. Dimensions of quality \& safety has a positive impact on food security. This is what put Singapore and Malaysia at the highest rank in terms ofquality \& safety dimensions. These findings indicate that food security is not only related to the availability of goods and services needed by the community but also related to the safety and quality of the goods consumed through the provision of clean water and sanitation that meets standards. The results of the scatter plot between the dimensions of safety \& quality and human development in ASEAN countries establish that there is a positive relationship between food security in the dimensions of safety \& quality and humandevelopment as shown in Figure 9.

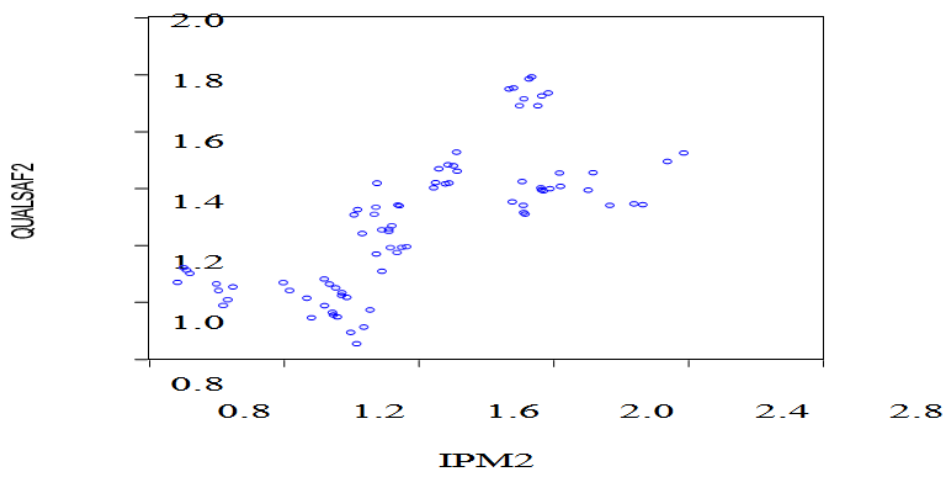

Fig. 9. Scatter Plot Safety \& Quality with Human Development

The dimension of natural resources has been proven to have a positive effect on human development. These findings indicate that the dimension of natural resources must receive special attention in human development because the scatter plot results of empirical evidence between natural resources and human development also show a positive relationship pattern as shown in Figure 10. This condition shows that food security does not only include aspects affordability of goods to be consumed, but also includes natural balance such as natural 
conditions that continue to occur from environmental damage, existing water conditions both quantity and quality, soil conditions. The state of rivers, lakes and oceans as well as mattersrelating to the political climate.

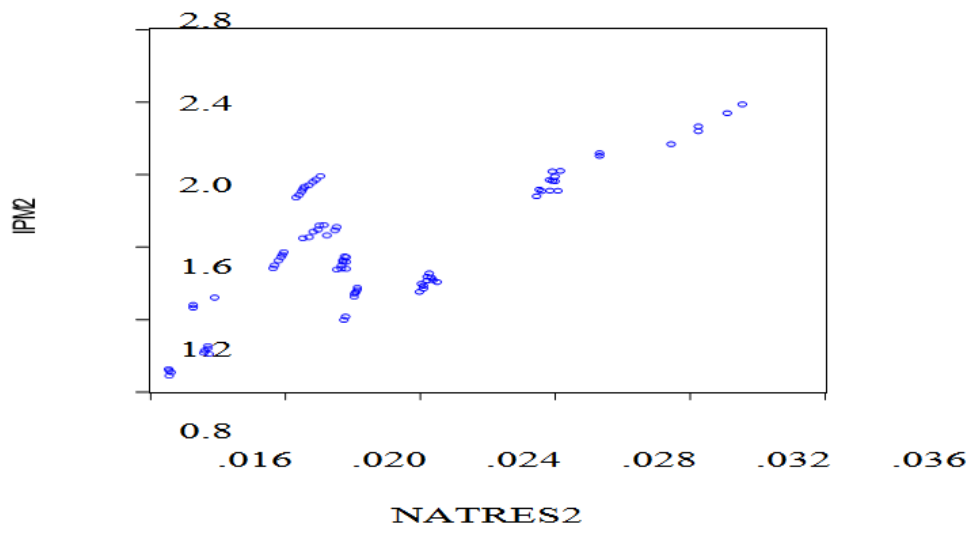

Fig. 10. Scatter Plot Natural Resources with Human Development

The availability dimension yielded findings that it was not proven to have a positive effect on human development. The availability dimension which includes the availability of food supply, food volatility, infrastructure in agriculture and government policies in the food sector is not a factor that has a significantimpact on food security.

These findings indicate that in terms of food security, food security and supply through food production is an aspect that contributes very little in shaping a country's food security. The ability of a country to maintain stability in food prices, the ease of obtaining goods, the fulfillment of the need for nutrition and supported by the availability of clean water and sanitation are the determinants of the achievement of the food security index. The above findings can be proven by factual conditions where Singapore as a country that is not a producer of food commodities but has a resilience index for the dimensions of affordability, availability, quality and safety and high natural resources so that it ranks very high in the world in terms of food security, which is ranked 19th out of 10. a total of 113 countries included in the calculation of the food security index. The opposite condition occurs in countries such as Indonesia, which is the largest producer of food commodities but ranks relatively low in food security because the agility aspect itself is not only an indicator of food availability, but many other indicators have low values. The low achievement of the food security index in the dimensions of affordability, quality and safety as well as natural resources has increasingly contributed significantly to the achievement of the Indonesian food security index.

The role of humans in achieving the level of economic activity is very important because the test results attest that human development has a positive effect on the level of economic activity. Qualified human beings must fulfill the human aspect of being healthy, having a quality level of education and being able to optimally meet their needs to support the achievement of optimal levels of economic activity. This is whatcauses Singapore with good quality human resources to produce a very high per capita income of $\$ 58,830$ per year, followed by Malaysia which has a per capita income of $\$ 12,478$ per year. 


\section{Conclusion}

The conclusions obtained from the results of this study are:

a. Food security rankings of countries in ASEAN occupy Singapore as the highest ranking country in the world in terms of food security in the world. Malaysia ranks second, followed by Thailand in the third. Indonesia, Vietnam, Myanmar and the Philippines are in the moderate ranking for the ASEAN region while the lowest ranking is occupied by Cambodia

b. The affordability dimension of food security has a positive effect on human development.

c. The availability dimension of food security does not have a positive effect on human development.

d. Food security in the dimensions of safety \& quality has been proven to have a positive effect on humandevelopment.

e. Food security in the natural resources dimension has been shown to have a positive effect on humandevelopment.

\section{Suggestion}

The results of this study indicate that achieving the optimal level of activity must be supported by the role of human quality. To increase quality of human beings, strong food security is needed where aspects thatmust be considered are how a country can guarantee the stability of food prices, the percentage of poor people can be minimized, the income gap is decreasing, the ease of public access to market, adequate food supply, low volatility of food production, fulfillment of the need for nutrition for the community, availability of good sanitation and clean water facilities and conducive natural conditions in encouraging the process economic activity.

\section{References}

[1] Global Food Security Index: Bulding Resilience in The Face of Rising Food-Security Risks (2018).

[2] Sow M. , Berete M., and Uche G.: The Relationship Between Safety, Security and Human Development in Africa, Int. Res. Vol., vol. 2, no. 4, pp. 3-11 (2015).

[3] VerwimpP.: Food Security, Violent Conflict and Human Development: Causes and Consequences. Belgium: World Health Organization (2012).

[4] Burchi F. and Muro P. D.: A Human Development and Capability Approach to Food Security: Conceptual Framework and Informational Basis (2012).

[5] Gani A. and Prasad B. C.: Food Security and Human Development, Int. J. Soc. Econ., vol. 34, no. 5, pp. 310-319 (2007).

[6] United Nations Development Program, Human Development Index. Geneva: World Health Organization (2015).

[7] Von Braun J., Bouis H. E., Kumar S. K., and Pandya-Lorch R.: Improving Food Security of The poor: Concept, Policy, and Programs. Washington DC: International Food Policy Research Institute (1992).

[8] Ballenger N. and Mabbs-Zeno C.: Treating Food Security and Food Aid Issues at the GATT, Food Policy, vol. 17, no. 4, pp. 264-276 (1992).

[9] Barraclough S. and Utting P.: Food Security Trends and Prospects in Latin America. United State: The Hellen Kellogg Institute of International Studies University of Notre 
Dame (1987).

[10] The International Coference on Nutrition, World Declaration on Nutrition. Rome: World Health Organization (1992).

[11] The World Food Summit, Food and Agriculture Organization of The United Nations. Rome: World Health Organization (1996). 